\begin{tabular}{c|c|c|}
\hline \hline & International Journal of Current Research in & \\
\hline & Biosciences and Plant Biology \\
\hline \\
\hline \hline
\end{tabular}

\title{
The Impact of the Emitted Dust from Zarka (Jordan) Petroleum Refinery on Plant Biodiversity
}

\author{
Sawsan A. Oran ${ }^{1 *}$ and Enas Al-Zo'ubi ${ }^{2}$ \\ ${ }^{1}$ Deparment of Biological Sciences, Faculty of Sciences, University of Jordan, Amman- Jordan \\ 'Al-Blaqa' Applied University, Al-Salt, Jordan \\ *Corresponding author.
}

\begin{abstract}
A b st ract
This study is concentrating on the present status of the plant biodiversity of the study area, Zarka (Jordan) based on plant collections from the study area. The wild flowering, vascular plants in the surrounding area have been surveyed and identified. The results showed a low botanical diversity of the study area in terms of the number and diversity of plant species recorded. A total number of 101 species belonging to 57 genera and 15 families is recorded. Wild plants are also reported like: Atriplex semibaccata, Conyza bonariensis, Peganum harmala, Lamarckia aurea, Hammada eigii, and others. The analysis of SEM shows many different elements deposited on the leaves of all plants that have been sampled and examined in the study area such as: $\mathrm{C}, \mathrm{Fe}, \mathrm{Mg}, \mathrm{Al}, \mathrm{Si}, \mathrm{Cl}$, $\mathrm{K}, \mathrm{Ca}, \mathrm{Ti}, \mathrm{S}, \mathrm{Na}$ and others. Dust particles deposited on leaves surfaces contain major concentrations of $\mathrm{CaO}, \mathrm{SiO} 2, \mathrm{~K} 2 \mathrm{O}, \mathrm{Al} 2 \mathrm{O} 3$ and $\mathrm{MgO}$. However the majority of plant species recorded in the study area is facing the danger of loss and degradation, as the area is severely exposed to the dust from the established refinery plant and others environmental and man effects.
\end{abstract}

\section{Article Info}

Accepted: 14May 2016

Available Online: 06 June 2016

\section{Ke ywords}

Petroleum refinery

Plant biodiversity

Pollution

\section{Introduction}

Zarka Province (Jordan) is characterized by its special phytogeography and special topography, in Jordan this region exists in the Irano-Turanian region that surrounds all the Mediterranean regions except the north. This region has mean amount of rainfall in this region is ranges from 50$150 \mathrm{~mm}$ per annum at most. Temperature ranges from (15$38^{\circ} \mathrm{C}$ ). The soil is mostly poor, eroded and mostly of the saline soil. The whole plants ecosystem has suffered a great deal of human interaction (Kasapligil, 1956). Therefore vast areas were destroyed and almost have no vegetation (Long, 1957).

Petroleum refinery has played an important role in solving the problem of our community, on the other hand; it is the major source of pollution in the surrounding areas of the refinery. Plant biodiversity faces the danger of degradation and loss of many plant species as a result of both man-made and natural factors. Changes in plant biodiversity can directly reduce sources of food, fuel, structural materials and medicinal or genetic resources (Al-Eisawi, 1996; Oran et al., 2014; Oran, 2015; Oran and Al-Eisawi, 2015). The present study has been carried out to explore the effects of petroleum refinery dust on plant diversity in Zarka Province, Jordan.

\section{Materials and methods}

Field trips and collection of plant specimens

Extensive field trips have been conducted in this 
botanical survey to the study area surrounding the petroleum refinery plant, from outside the refinery up to $13 \mathrm{Km}$ East, Zarka, Jordan (Fig. 1). The localities have been chosen randomly according to the availability of plant species.

Fig. 1: The study area, $\square$ Zarka (Jordan).

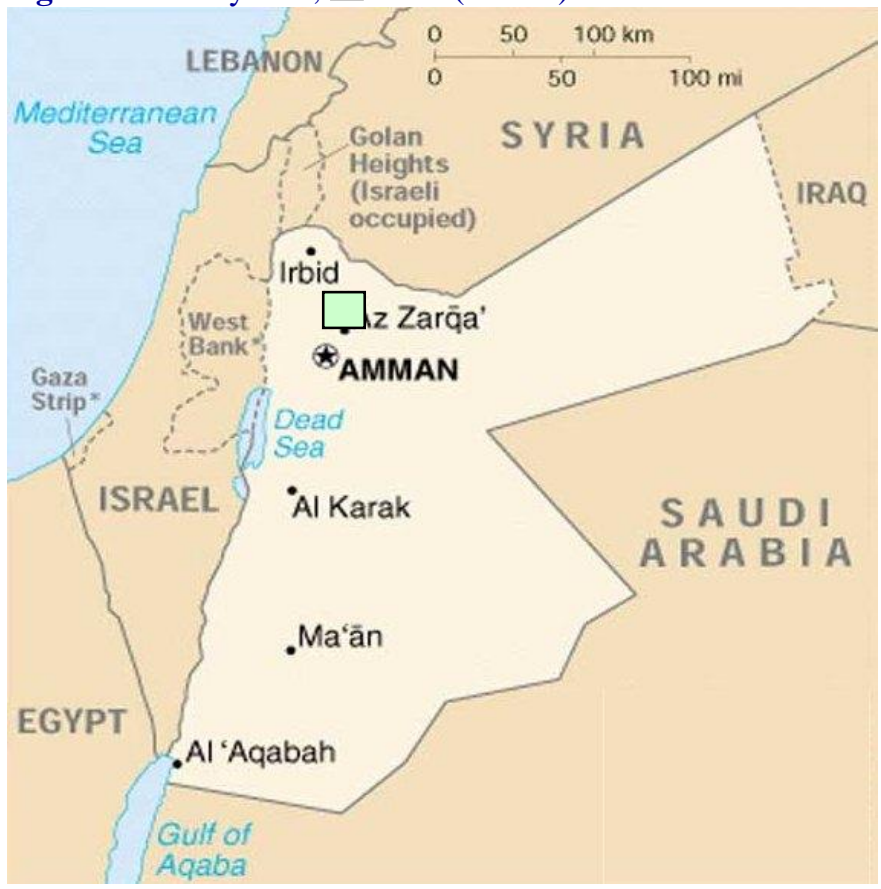

\section{Plant material preparation}

Collection of fresh plant specimens were placed in plastic bags, to prevent loss of moisture when they closed securely, and each collection has been kept separately. After that they undergo several steps of preparations, they were:

Pressing and drying specimens: This is device by means of which fresh specimens are pressed flat and quickly dried using pressers available at the Herbarium laboratories / University of Jordan.

Poisoning: In order to protect the plants from insect attacks or fungal infections, it is advisable to dip them in poison before they are finally taken out of the press. The solution most common used for this purpose consists of: 22.5 Mercuric chloride $\mathrm{HgCl} 2,52.5$ Ammonium chloride $\mathrm{NH} 4 \mathrm{Cl}$, dissolved in as little water as possible, and to this added 1.5 liter of $96 \%$ alcohol (Ethanol).

Mounting:This is process by which specimens are prepared for the permanent files. The pressed and dried plants are securely attached to one side of a sheet of mounting paper. The paper should be good quality white paper (lightweight board), they varying with the kind of specimens. Specimens attached to the sheets by using strips of white gummed cloth.

\section{Identification of plant specimens}

The identification of plants was done based on using floras for the region such as Flora Palaestina (Parts 1, 2, 3 and 4) (Zohary, 1966-1972; Al-Eisawi, 1982).

\section{Scanning Electron Microscope (SEM) preparations}

The (SEM) was used for this experiment because of its usefulness in prevailing and analyzing small particles on leaf surfaces. Before using the SEM, samples were dried and coated with a thin layer of conductive carbon or metal (in this case it is gold), to prevent a build-up of charges on the surface of the sample.

\section{SEM analysis}

The sample plate (stubs) with the leaf samples were placed into SEM sample chamber after preparation. The high vacuum pressure was used to evacuate the chamber, and a high voltage was also used to turn the electron beam on for providing the best backscatter electron (BE) and $\mathrm{X}$ - ray information. The method used to count and measure the particles on the leaves was X- ray microanalysis. In this type of analysis, the area of analysis and parameters are set, and the program built in the computer controls the data analysis. The $\mathrm{X}$ - ray microanalysis of the particles determines which elements are present in the particles found, and places them in a spectrum. The connected device computer calculates and provides the elemental composition data of each element found on the surface of the leaf for every sample, and digital micrograph is given. In this experiment different magnifications were set according to the sample used, magnification was between $(10000-1000 x)$. The magnification of each micrograph was illustrated.

\section{Results and discussion}

The plant species recorded during the study belonged to 15 families (Table 1 and Fig. 2). The majority of the plant species were herbs and shrubs were minimum (8 species) (Table 2). Acacia albida was the only tree species recorded in the study. Among the recorded plants, 29 species were belonged to rare category and 8 species were endemic plants (Table 3 ). 
Table 1. List of plants in the study area with their respective families.

\begin{tabular}{|c|c|c|}
\hline Family & Genus & Species \\
\hline \multirow[t]{23}{*}{ Asteraceae } & Anthemis & palaestina Reuter \\
\hline & & pseudocotula Boiss. \\
\hline & Astariscus & graveolens Less. \\
\hline & Astragalus & curaganae Fisch. Mey. \\
\hline & Calendula & arvensis $\mathrm{L}$. \\
\hline & & tenuis (Boiss.et Blanche)Bornm \\
\hline & & tripterocarpa Rupr. \\
\hline & Cardus & australis Pomel. \\
\hline & & getulus Pomel. \\
\hline & Carthamus & tenuis (Boiss.et Blanche) Bornm \\
\hline & Centaurea & calcitrapa $\mathrm{L}$ \\
\hline & & iberica Spreng. \\
\hline & & pallescens Delile \\
\hline & & sinaica $\mathrm{DC}$. \\
\hline & Conyza & bonariensis (L.) Cronquist \\
\hline & & candensis (L.) Cronquist \\
\hline & Crepis & seneciodes Delile \\
\hline & Lactuca & orientalis Boiss. \\
\hline & Matricaria & aurea (Leofl.) Schultz Bip. \\
\hline & Onopordum & alexandrinum Boiss. \\
\hline & & macrocephalum Eig \\
\hline & & palaestinum Eig \\
\hline & Senecio & vernalis Waldst. \& Kit \\
\hline Boraginaceae & Heliotropium & suaveolens Bieb. \\
\hline \multirow[t]{10}{*}{ Brassicaeae } & Brassica & nigra (L.) Koch \\
\hline & & tournefortii Gouan \\
\hline & Cardaria & draba $\mathrm{L}$. \\
\hline & Clypeola & jonthlaspi L. \\
\hline & Diplotaxis & acris (Forssk) Boiss. \\
\hline & & erucoides (L.) DC. \\
\hline & & viminea (L.) DC. \\
\hline & Eruca & sativa Mill. \\
\hline & Matthiola & parviflora $\mathrm{L}$. \\
\hline & Nasturtium & officinale $\mathrm{R} . \mathrm{Br}$. \\
\hline \multirow[t]{9}{*}{ Chenopodiaceae } & Anabasis & articulata $L$. \\
\hline & & syriaca Iljin \\
\hline & Arthocnemum & fruticosum (L.) Moq. \\
\hline & & perenne (Mill.) Moss. \\
\hline & Atriplex & dimorphostegia Kar.et Kit \\
\hline & & halimus L. \\
\hline & & lasiantha Boiss. \\
\hline & & leucoclada Boiss. \\
\hline & & murale $\mathrm{L}$. \\
\hline \multirow[t]{7}{*}{ Chenopodiaceae } & Atriplex & nitens Schkuhr \\
\hline & & semibaccata $\mathrm{R} . \mathrm{Br}$. \\
\hline & & stylosa Viv. \\
\hline & & tatarica $\mathrm{L}$. \\
\hline & Bassia & muricata $\mathrm{L}$. \\
\hline & Chenopodium & album L. \\
\hline & & murale L. \\
\hline
\end{tabular}




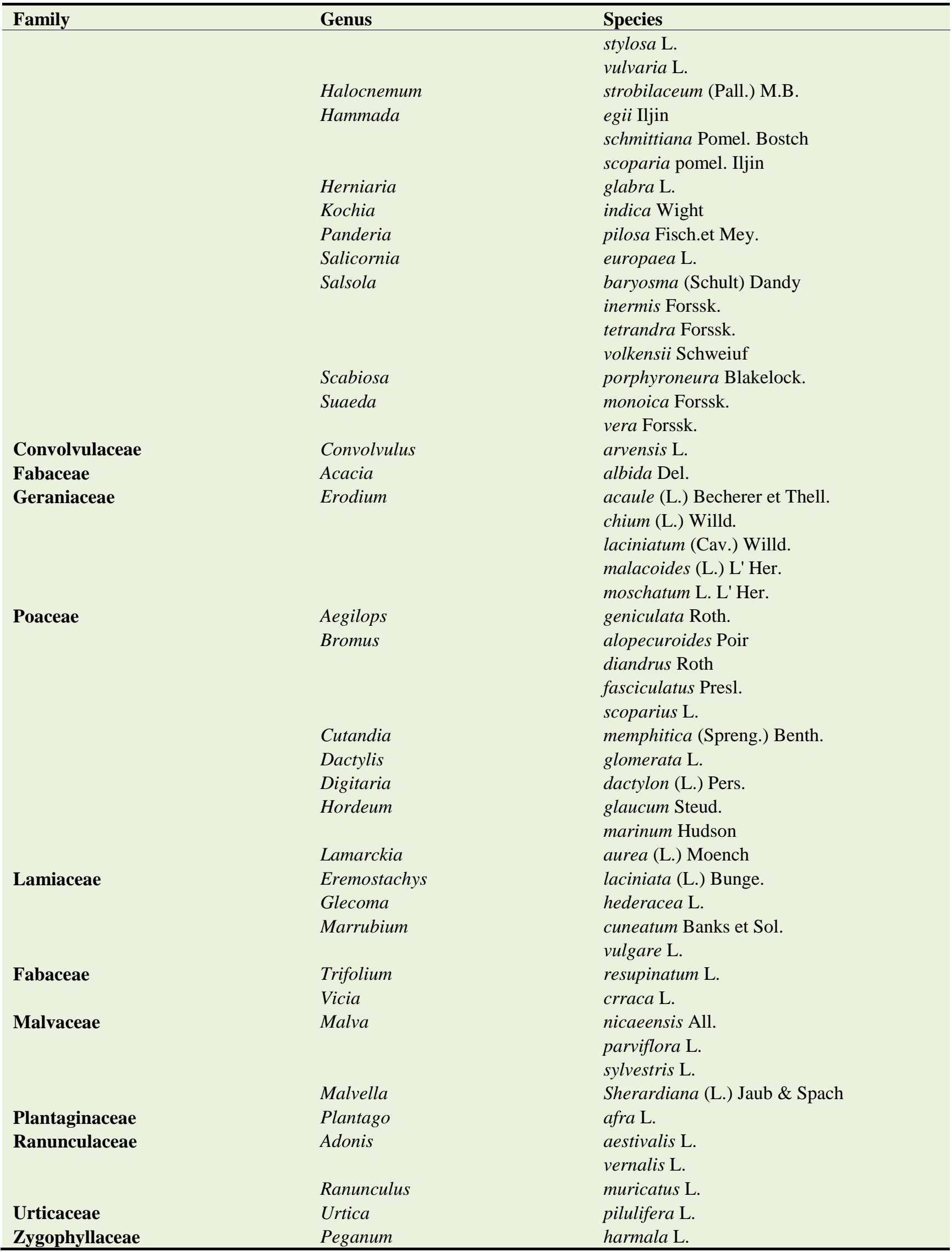


(a)

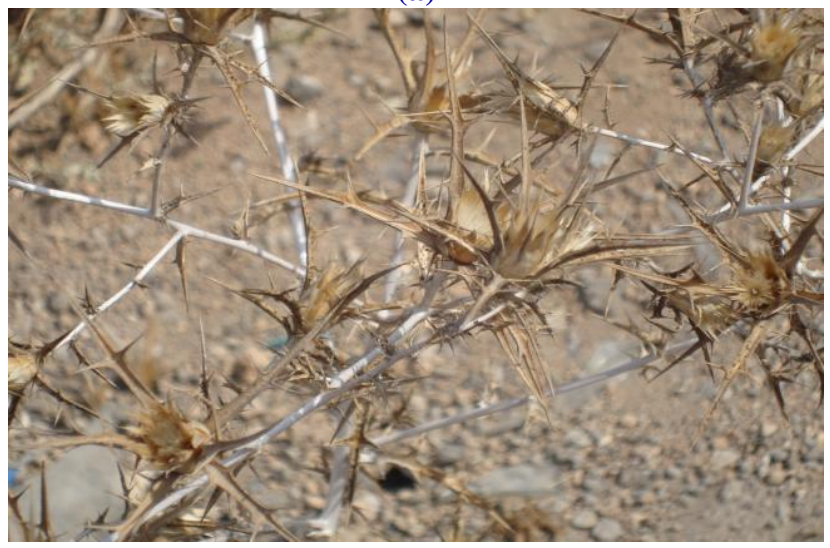

(c)

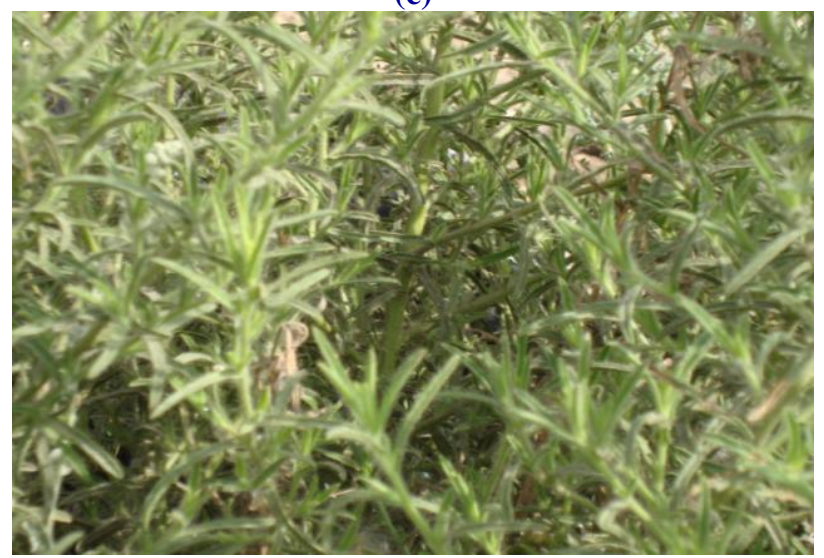

(b)

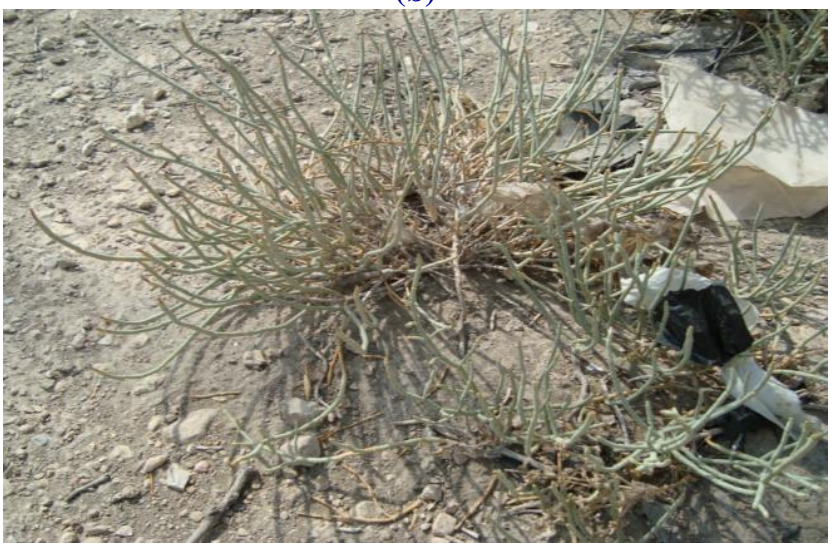

(d)

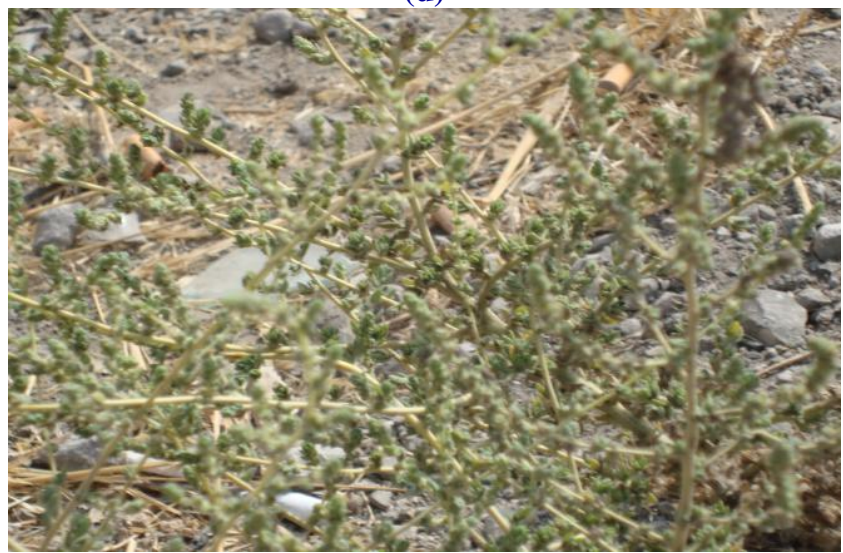

Fig. 2: Some of plant species that recorded in the study area. (a) Centaurea arabica (Spreng.), (b) Anabasis syriaca Iljin, (c) Peganum harmala L. and (d) Hammada eigii Iljin.

Table 2. The Plant Species recorded in the study area showing their habitats (Trees, Shrubs and Herbs).

\begin{tabular}{|c|c|c|c|c|c|}
\hline Family & Genus & Species & Herbs & Shrubs & Trees \\
\hline \multirow[t]{19}{*}{ Asteraceae } & Anthemis & palaestina Reuter & + & & \\
\hline & & pseudocotula Boiss. & + & & \\
\hline & Astaricus & graveolens Less. & + & & \\
\hline & Astragalus & curaganae Fisch. Mey. & + & & \\
\hline & Calendula & arvensis L. & + & & \\
\hline & & tenuis (Boiss.et Blanche)Bornm & + & & \\
\hline & & tripterocarpa Rupr. & + & & \\
\hline & Cardus & australis Pomel. & + & & \\
\hline & & getulus Pomel. & + & & \\
\hline & Carthmus & tenuis (Boiss.et Blanche) Bornm & + & & \\
\hline & Centaurea & calcitrapa $\mathrm{L}$. & + & & \\
\hline & & iberica Spreng. & + & & \\
\hline & & pallescens Delile & + & & \\
\hline & & sinaica DC. & + & & \\
\hline & Conyza & bonariensis (L.) Cronquist & + & & \\
\hline & & candensis (L.) Cronquist & + & & \\
\hline & Crepis & seneciodes Delile & + & & \\
\hline & Lactuca & orientalis Boiss. & + & & \\
\hline & Matricaria & aurea (Leofl.) Schultz Bip. & + & & \\
\hline
\end{tabular}




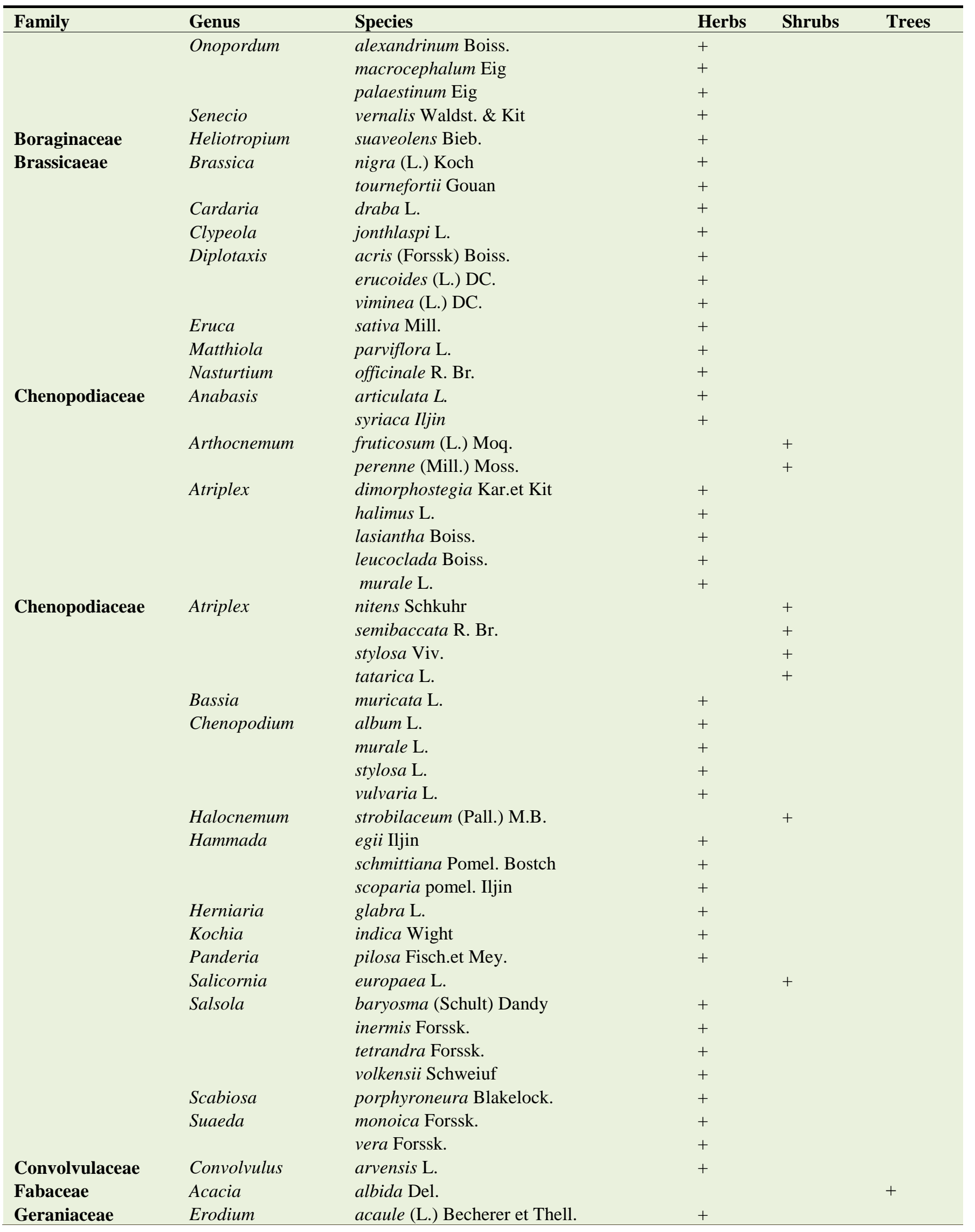




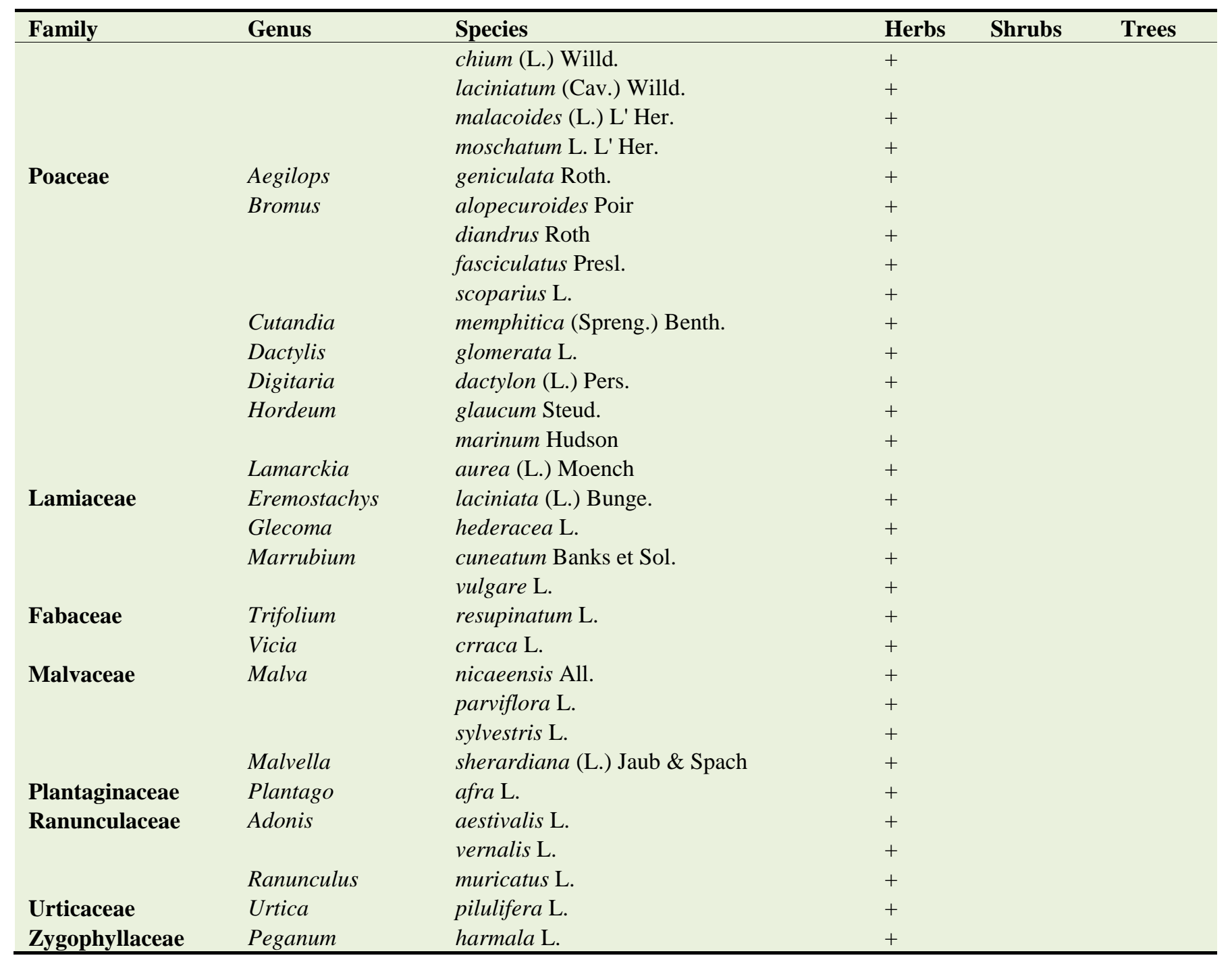

Table 3. The Plant Species recorded in the study area showing their potentials and ecological status (M: medicinal, P: poisonous, C: common, R: rare, En: endemic).

\begin{tabular}{|c|c|c|c|c|c|c|c|}
\hline Family & Genus & Species & $\mathbf{M}$ & $\mathbf{P}$ & $\mathbf{C}$ & $\mathbf{R}$ & En \\
\hline Asteraceae & $\begin{array}{l}\text { Anthemis } \\
\text { Astaricus } \\
\text { Astragalus } \\
\text { Calendula } \\
\text { Cardus } \\
\text { Carthmus } \\
\text { Centaurea }\end{array}$ & $\begin{array}{l}\text { palaestina } \text { Reuter } \\
\text { pseudocotula } \text { Boiss. } \\
\text { graveolens } \text { Less. } \\
\text { curaganae } \text { Fisch. Mey. } \\
\text { arvensis } \text { L. } \\
\text { tenuis (Boiss.et Blanche)Bornm } \\
\text { tripterocarpa } \text { Rupr. } \\
\text { australis } \text { Pomel. } \\
\text { getulus } \text { Pomel. } \\
\text { tenuis (Boiss.et Blanche) Bornm } \\
\text { calcitrapa } \text { L. } \\
\text { iberica } \text { Spreng. } \\
\text { pallescens } \text { Delile } \\
\text { sinaica } \text { DC. } \\
\text { bonariensis } \text { (L.) Cronquist } \\
\text { candensis } \text { L.) Cronquist }\end{array}$ & + & & $\begin{array}{l}+ \\
+ \\
+ \\
+\end{array}$ & $\begin{array}{l}+ \\
+\end{array}$ & \\
\hline
\end{tabular}




\begin{tabular}{|c|c|c|c|c|c|c|c|}
\hline Family & Genus & Species & $\mathbf{M}$ & $\mathbf{P}$ & $\mathbf{C}$ & $\mathbf{R}$ & En \\
\hline \multirow[t]{7}{*}{ Asteraceae } & Crepis & seneciodes Delile & & & + & & \\
\hline & Lactuca & orientalis Boiss. & & & + & & \\
\hline & Matricaria & aurea (Leofl.) Schultz Bip. & + & & & & \\
\hline & Onopordum & alexandrinum Boiss. & & & & + & \\
\hline & & macrocephalum Eig & & & & + & \\
\hline & & palaestinum Eig & & & & + & \\
\hline & Senecio & vernalis Waldst. \& Kit & + & & & & + \\
\hline Boraginaceae & Heliotropium & suaveolens Bieb. & & & & + & \\
\hline \multirow[t]{10}{*}{ Brassicaeae } & Brassica & nigra (L.) Koch & + & & & & \\
\hline & & tournefortii Gouan & & & + & & \\
\hline & Cardaria & draba $\mathrm{L}$. & & & & + & \\
\hline & Clypeola & jonthlaspi $\mathrm{L}$. & & & & & \\
\hline & Diplotaxis & acris (Forssk) Boiss. & & & & + & \\
\hline & & erucoides (L.) DC. & & & & + & \\
\hline & & viminea (L.) DC. & & & & + & \\
\hline & Eruca & sativa Mill. & + & & & + & \\
\hline & Matthiola & parviflora $\mathrm{L}$. & & & + & & \\
\hline & Nasturtium & officinale $\mathrm{R}$. Br. & + & & & + & \\
\hline \multirow[t]{24}{*}{ Chenopodiaceae } & Anabasis & articulata $L$. & + & & & + & \\
\hline & & syriaca Iljin & + & & & + & \\
\hline & Arthocnemum & fruticosum (L.) Moq. & & & + & & \\
\hline & & perenne (Mill.) Moss. & & & + & & \\
\hline & Atriplex & dimorphostegia Kar.et Kit & + & & & & \\
\hline & & halimus L. & + & & & & \\
\hline & & lasiantha Boiss. & & & + & & \\
\hline & & leucoclada Boiss. & & & + & & \\
\hline & & murale L. & & & + & & \\
\hline & & nitens Schkuhr & & & + & & \\
\hline & & semibaccata $\mathrm{R} . \mathrm{Br}$. & + & & + & & \\
\hline & & stylosa Viv. & & & + & & \\
\hline & & tatarica $\mathrm{L}$. & & & + & & \\
\hline & Bassia & muricata $\mathrm{L}$. & & & + & & \\
\hline & Chenopodium & album L. & + & & & & \\
\hline & & murale L. & & & + & & \\
\hline & & stylosa $\mathrm{L}$. & & & + & & \\
\hline & & vulvaria $\mathrm{L}$. & & & + & & \\
\hline & Halocneтит & strobilaceum (Pall.) M.B. & & & + & & + \\
\hline & Hammada & egii Iljin & + & & & & + \\
\hline & & schmittiana Pomel. Bostch & & & + & & \\
\hline & & scoparia pomel. Iljin & + & & & & \\
\hline & Herniaria & glabra L. & & & + & & \\
\hline & Kochia & indica Wight & & & + & & \\
\hline \multirow[t]{9}{*}{ Chenopodiaceae } & Panderia & pilosa Fisch.et Mey. & & & & + & \\
\hline & Salicornia & europaea L. & + & & + & & \\
\hline & Salsola & baryosma (Schult) Dandy & + & & & & \\
\hline & & inermis Forssk. & & & + & & \\
\hline & & tetrandra Forssk. & & & + & & \\
\hline & & volkensii Schweiuf & & & + & & \\
\hline & Scabiosa & porphyroneura Blakelock. & & & & + & \\
\hline & Suaeda & monoica Forssk. & + & & & & \\
\hline & & vera Forssk. & + & & & & \\
\hline
\end{tabular}




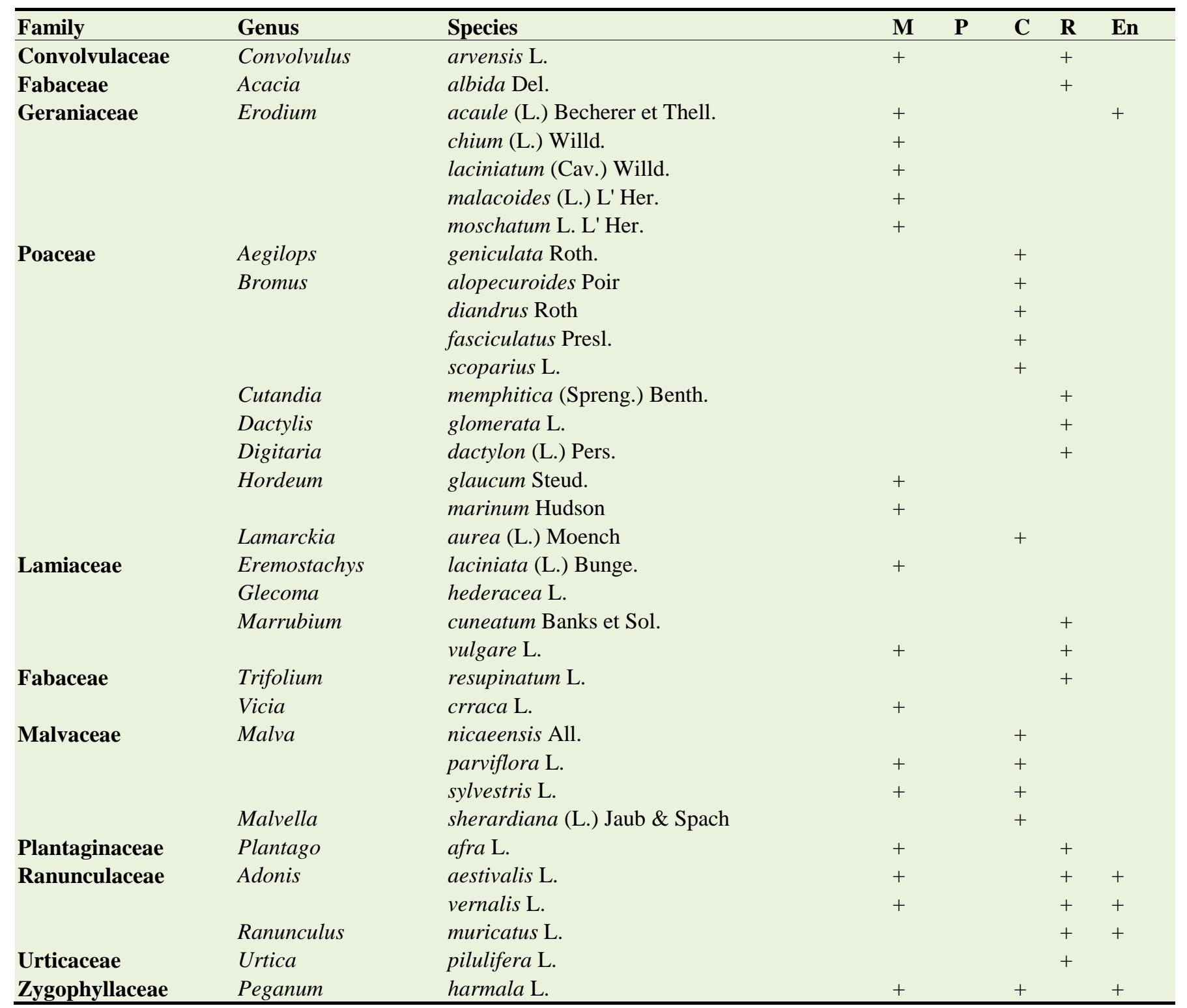

(a)

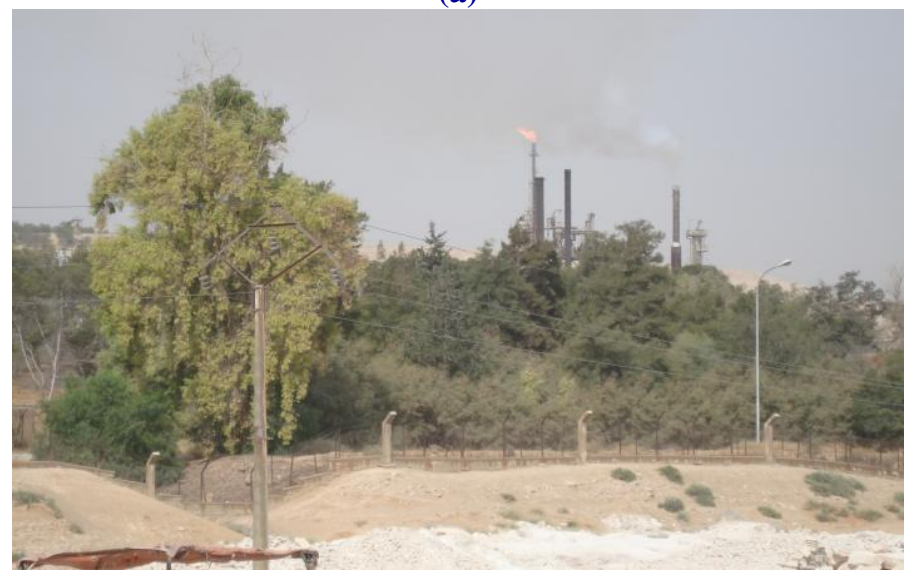

(b)

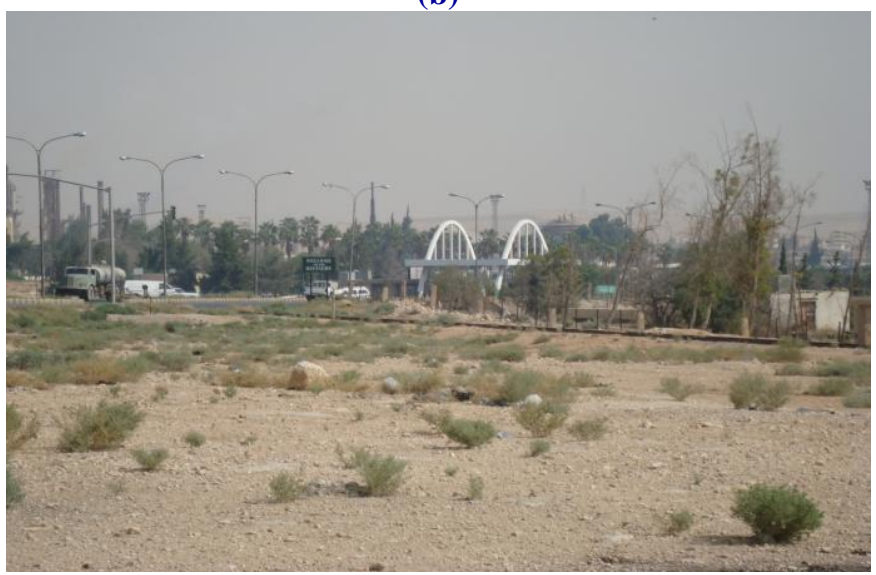

Fig. 3: The surrounding area of the Petroleum refinery. (a) Showing the Dust Emitted from the refinery; (b) Plant biodiversity in the study area. 
Scanning Electron Microscope (SEM) micrographs have also been carried out to describe the impact of pollution caused by the emitted dust from the refinery on the plant biodiversity of the surrounding area of petroleum refinery (Fig. 3 a, b). The analysis of SEM shows many different elements deposited on the leaves of all plants that have been sampled and examined in the study area such as: $\mathrm{C}, \mathrm{Fe}, \mathrm{Mg}, \mathrm{Al}, \mathrm{Si}, \mathrm{Cl}, \mathrm{K}, \mathrm{Ca}, \mathrm{Ti}, \mathrm{S}, \mathrm{Na}$ and others. The results indicated that plant species growing near the refinery were covered with higher amounts of dust accumulations than those growing far away from the factory. Dust particles deposited on leaves surfaces contain major concentrations of $\mathrm{CaO}, \mathrm{SiO} 2, \mathrm{~K} 2 \mathrm{O}, \mathrm{Al} 2 \mathrm{O} 3$ and $\mathrm{MgO}$.

It can be observed from micrographs (Figs. 4a-4d) that there is a considerable amount of dust accumulated in all of the four plant species that have been collected and sampled. Plants must exchange gasses through their leaves in order to conduct photosynthesis and respiration; they also must permit evaporation /transpiration in order to assist in the movement of water from the ground to leaves, where it is needed to build carbohydrates. Yet, if transpiration is uncontrolled, a plant may become desiccated (dehydrated) and die, this process is controlled by the stomata, which are microscopic pores, located in both epidermal layers of the leaf. These allow air into and out the leaf, which is how the plant takes in $\mathrm{CO} 2$ and lets out $\mathrm{O} 2$, and allow water vapor out in the process of transpiration. As air passes through the stomata, most of the dust particles will not passes through the stomata but will rather land on the leaf's outer surface and close most of the stomatal pores. (a)

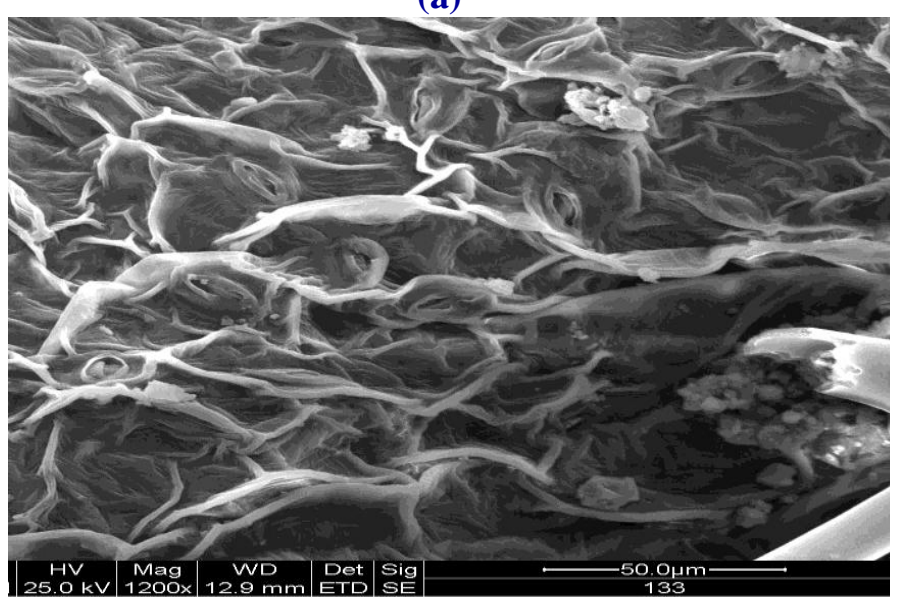

(c)

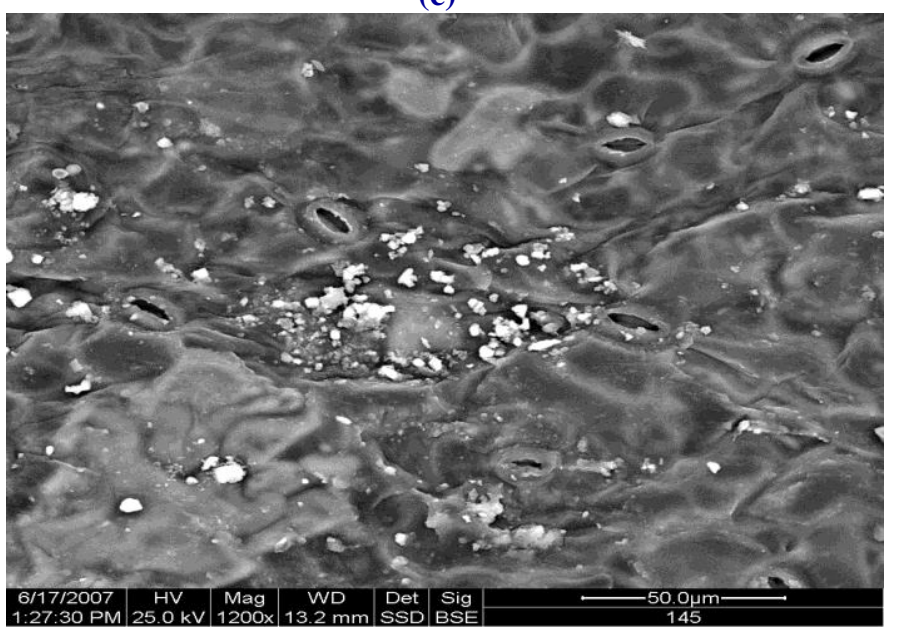

(b)

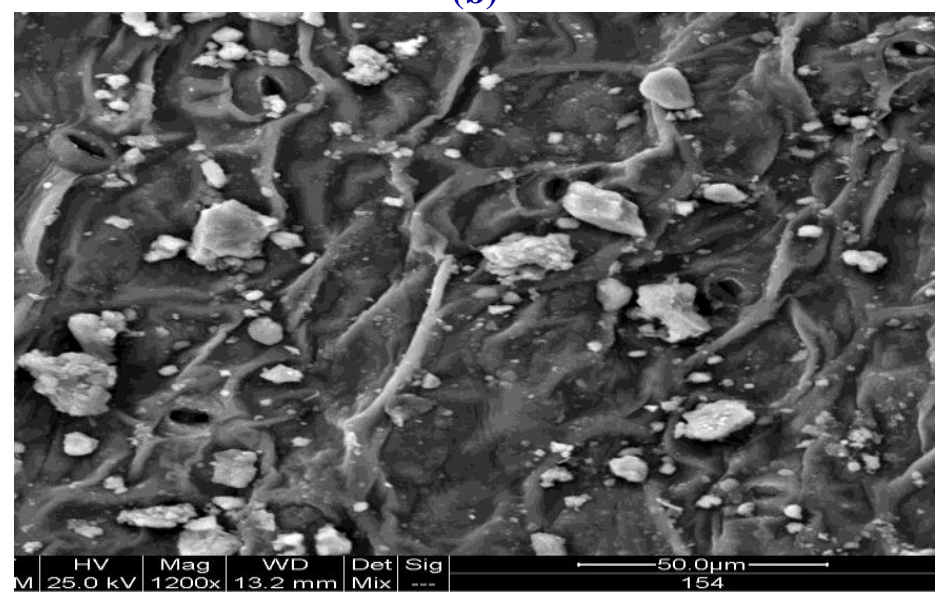

(d)

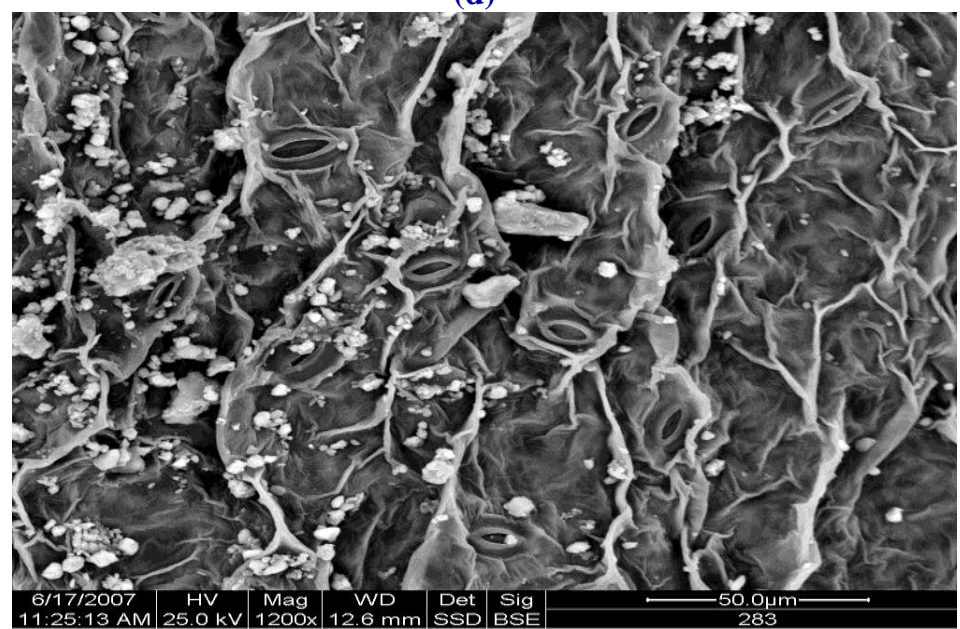

Fig. 4: SEM micrographs of leaves of plants collected from study site. (a) Malvella sherardiana (sample leaf-133), (b) Brassica tournefortii (sample leaf-145), (c) Centaurea iberica (sample leaf-154) and (d) Atriplex leucoclada (sample leaf-283). 
Dust emitted from the chimneys of the refinery contains major concentrations of $\mathrm{C}, \mathrm{Fe}, \mathrm{Mg}, \mathrm{Al}, \mathrm{Si}, \mathrm{Cl}, \mathrm{K}, \mathrm{Ca}, \mathrm{Ti}$, $\mathrm{S}, \mathrm{Na}$; these elements are transported with particulates and are known for their effect on air pollution as reported by previous studies, but this current analysis shows that dust particles deposited on leaves surfaces contain major concentrations of $\mathrm{CaO}, \mathrm{SiO} 2, \mathrm{~K} 2 \mathrm{O}, \mathrm{Al} 2 \mathrm{O} 3$ and $\mathrm{MgO}$ (Figs. 5a-5d), these major elements are known to be the components of the plant cells, but at the same time $\mathrm{Si}$,
$\mathrm{Al}, \mathrm{K}$ and part of $\mathrm{O}$ and $\mathrm{Ca}$ are the main components of clay and limestone, which are the raw materials for cement production and could come to the plants from the soil itself. It can be concluded that the study area is of low botanical diversity, and the plant species in the study area are facing the danger of loss and degradation. Petroleum refinery dust is a major pollution source in this area, and has many effects eventually on the environment and the community.

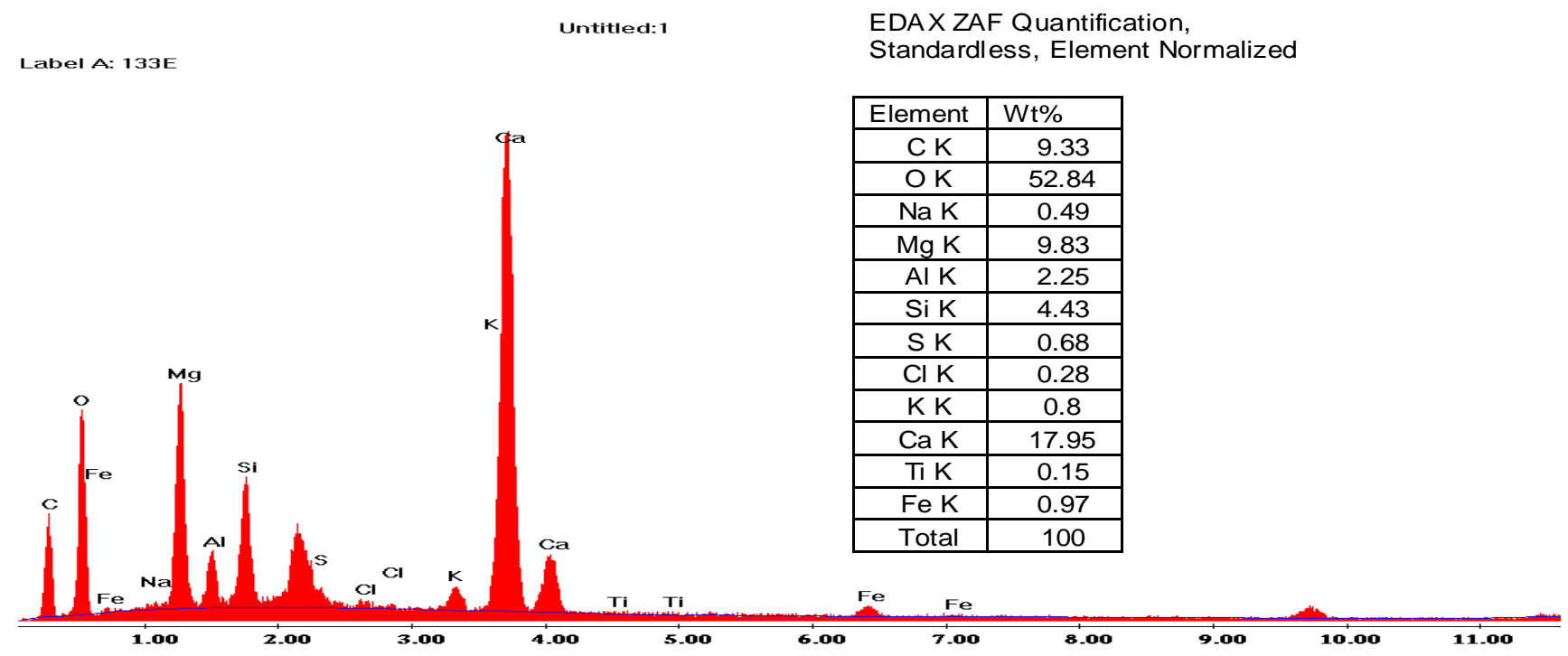

Fig. 5a: X- Ray spectrum of particles showing the elemental contents in Malvella sherardiana leaf (sample leaf-133).

Label A: 145E

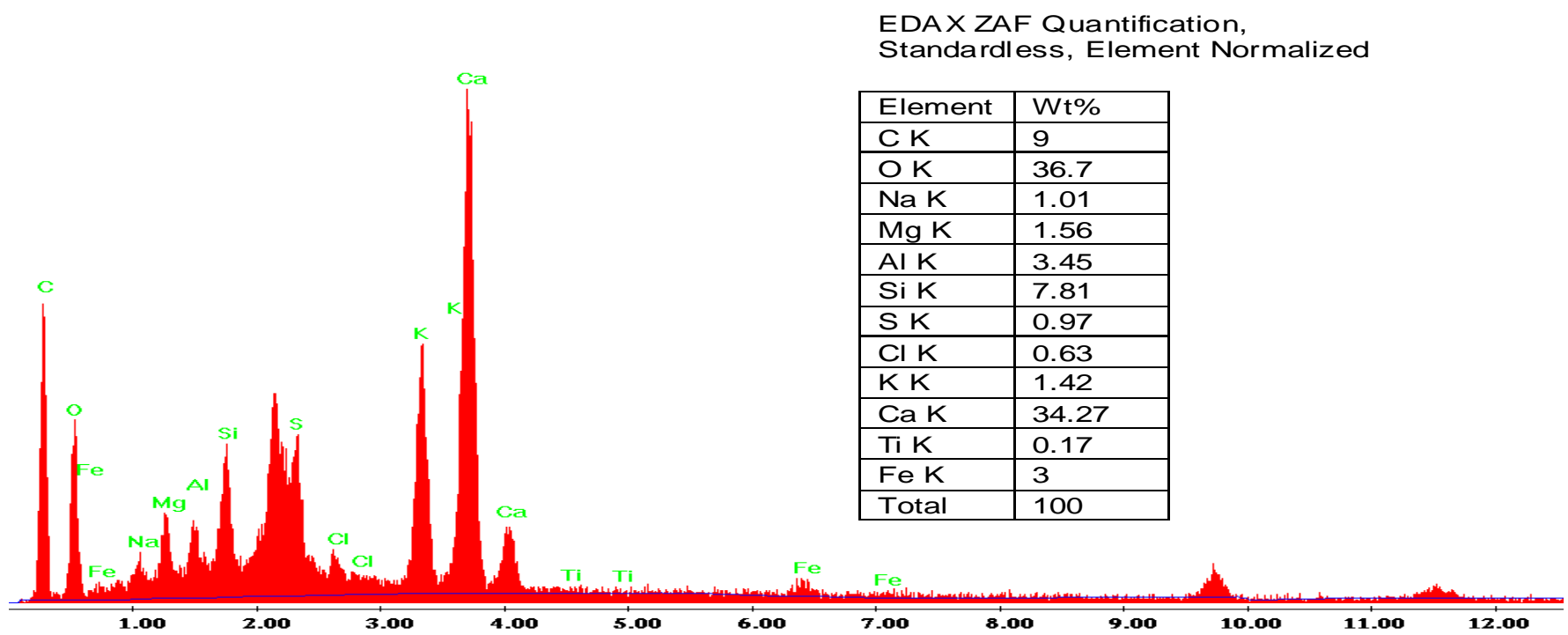

Fig. 5b: X- Ray spectrum of particles showing the elemental contents in Brassica tournefortii (sample leaf-145). 
Label A: 154

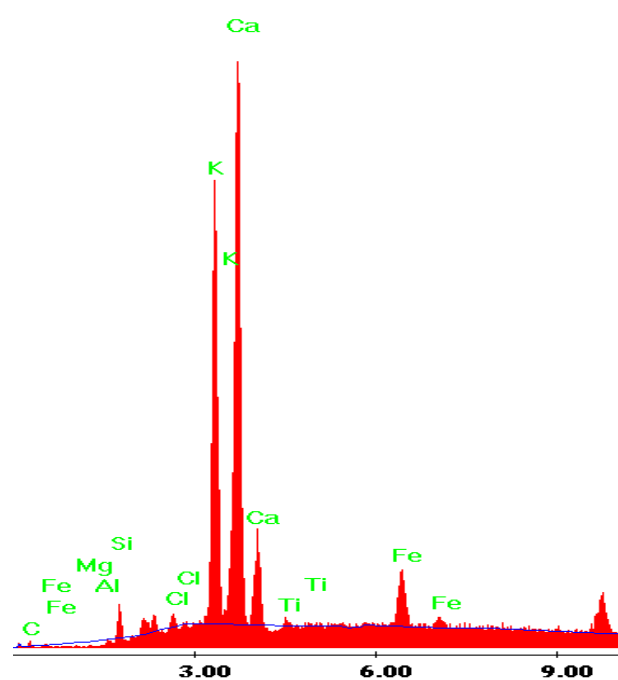

EDAX ZAF Quantification, Standardless, Element Normalized

\begin{tabular}{|l|l|}
\hline Element & $\mathrm{Wt} \%$ \\
\hline $\mathrm{C} \mathrm{K}$ & 0.85 \\
\hline $\mathrm{O} \mathrm{K}$ & 2.81 \\
\hline $\mathrm{Si} \mathrm{K}$ & 2.07 \\
\hline $\mathrm{Cl} \mathrm{K}$ & 0.69 \\
\hline $\mathrm{K} \mathrm{K}$ & 28.06 \\
\hline $\mathrm{Ca} \mathrm{K}$ & 52.14 \\
\hline Ti K & 0.81 \\
\hline Fe K & 12.57 \\
\hline Total & 100 \\
\hline
\end{tabular}

Fig. 5c: X- Ray spectrum of particles showing the elemental contents in Centaurea iberica (sample leaf-154).

Label A: 283

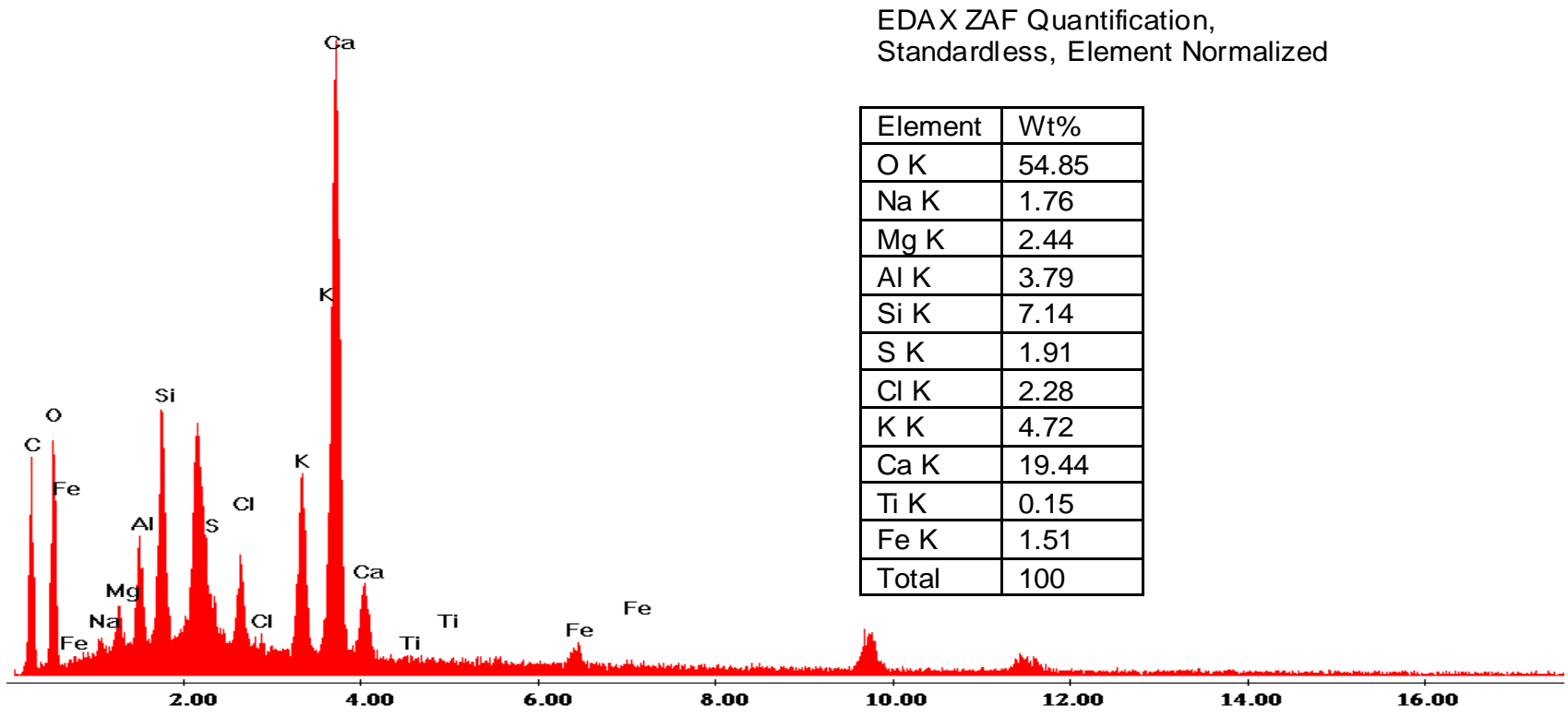

Fig. 5d: X- Ray spectrum of particles showing the elemental contents in Atriplex leucoclada (sample leaf-283).

\section{Conflict of interest statement}

Authors declare that they have no conflict of interest.

\section{Acknowledgement}

The authors acknowledge Al-Balqa' Applied University for the financial support and Miss. Asma Bzour, Research Assistant for her dedicated efforts.

\section{References}

Al-Eisawi, D. M., 1982. List of Jordan vascular plants. Mitt. Bot. Mứnchen, 18, 79-182.

Al-Eisawi, D. M., 1996. Vegetation of Jordan. UNESCOCAIRO OFFICE, Regional office for science and technology for the Arab States.

Kasapligil, B., 1956. Report to the Government of the Hashemite Kingdome of Jordan, on an Ecological Survey of the Vegetation in Relation to Forestry and Grazing. 
UNESCO/FAO, Rome.

Long, G., 1957. The Bioclimatology and Vegetation of East Jordan. UNESCO\FAO, Rome.

Oran, SA., Abu Zahra, Hammad (2014). The impact of the cement dust emitted from the south cement factory in Tafila/ Jordan on plant diversity of the surrounding area. Int. J. Biodiv. Conserv. 6(5), 400-414.

Oran, S. A., Al-Eisawi, D. M., 2015. Etnnobotanical survey of the medicinal plants in the central mountains (north-south) in Jordan. J. Biodiv. Environ. Sci. 6(3), 381-400.

Oran, S. A., 2015. Flora of Bader Al-Jadida county, western high mountains of Amman-Jordan. Int. J. Herbal Med. 3(4), 49-59.

Zohary, M., 1966-1972. Flora Palaestina. Part 1, 2, 3 and 4. The Israel Academy of Sciences and Humanities, Jerusalem.

\section{How to cite this article:}

Oran, S. A., Al-Zo'ubi, E., 2016. The impact of the emitted dust from Zarka (Jordan) petroleum refinery on plant biodiversity. Int. J. Curr. Res. Biosci. Plant Biol. 3(6), 1-13.

doi: http://dx.doi.org/10.20546/ijcrbp.2016.306.001 